\title{
A Study on Profitability Analysis of Private Sector Banks In India
}

\author{
Brindadevi . $\mathrm{V}^{1}$ \\ ${ }^{1}$ (Assistant Professor of Commerce, MGR College / Periyar University, India)
}

\begin{abstract}
The objective of this study was overall profitability analysis of different private sectors banks in India based on the performances of profitability ratios like interest spread, net profit margin, return on long term fund, return on net worth \& return on asset. Profitability is a measure of efficiency and control it indicates the efficiency or effectiveness with which the operations of the business are carried on. Recording profitability for the past period or projecting profitability for the coming period, measuring profitability is the most important measure of the success of the business. A business that is not profitable cannot survive. Conversely, a business that is highly profitable has the ability to reward its owners with a large return on their investment. Increasing profitability is one of the most important tasks of the business managers. Managers constantly look for ways to change the business to improve profitability. These potential changes can be analyzed with a support of income statement and balance sheet.
\end{abstract}

Keywords: AXIS, ICICI, KVB, SIB

\section{Introduction}

All those banks where greater parts of stake or equity are held by the private shareholders and not by government are called "private-sector banks". These are the major players in the banking sector as well as in expansion of the business activities India. The present private-sector banks equipped with all kinds of contemporary innovations, monetary tools and techniques to handle the complexities are a result of the evolutionary process over two centuries. They have a highly developed organsational structure and are professionally managed. Thus they have grown faster and stronger since past few years.

Private-sector banks have been functioning in India since the very beginning of the banking system. Initially, during 1921, the private banks like bank of Bengal, bank of Bombay and bank of Madras were in service, which all together formed Imperial Bank of India.

Reserve Bank of India (RBI) came in picture in 1935 and became the centre of every other bank taking away all the responsibilities and functions of Imperial bank. Between 1969 and 1980 there was rapid increase in the number of branches of the private banks. In April 1980, they accounted for nearly 17.5 percent of bank branches in India. In 1980, after 6 more banks were nationalized, about 10 percent of the bank branches were those of private-sector banks. The share of the private bank branches stayed nearly same between 1980 and 2000. Then from the early 1990s, RBI's liberalization policy came in picture and with this the government gave licences to a few private banks, which came to be known as new private-sector banks.

\subsection{Private-Sector Banks}

The banks, which came in operation after 1991, with the introduction of economic reforms and financial sector reforms are called "new private-sector banks". Banking regulation act was then amended in 1993, which permitted the entry of new private-sector banks in the Indian banking sector. However, there were certain criteria set for the establishment of the new private-sector banks, some of those criteria being:

a) The bank should have a minimum net worth of Rs. 200 crores.

b) The promoters holding should be a minimum of $25 \%$ of the paid-up capital.

c) Within 3 years of the starting of the operations, the bank should offer shares to public and their net worth must increased to 300 crores.

\section{Review Of Literature}

Review of literature is essential for every research to carry on investigation successfully. Hence the present study is also based on the following review.

B.Satish Kumar (2008), in his article on an evaluation of the financial performance of Indian private sector banks wrote Private sector banks play an important role in development of Indian economy. After liberalization the banking industry underwent major changes. The economic reforms totally have changed the banking sector. RBI permitted new banks to be started in the private sector as per the recommendation of Narashiman committee. The Indian banking industry was dominated by public sector banks. But now the situations have changed new generation banks with used of technology and professional management has gained a reasonable position in the banking industry. 


\section{Objectives Of The Study}

a) To highlight the various profitability analysis of some selected private sectors banks (i.e.,) AXIS, ICICI. Karur vysya bank (KVB), South India bank (SIB).

b) To analyze the overall profitability of banks (i.e.,) Interest spread, Net profit margin, Return on Long term fund, Return on Net worth, \& Return on asset.

\section{Scope Of Study}

The study is about the role of profitability analysis of private sectors banks in India. It is mainly dealt with the Profitability ratios show a company's overall efficiency and performance. A variety of Profitability Ratios (Decision Tool) can be used to assess the financial health of a business.

\section{Period Of Study}

The study covers a period of 10 years from 2002- 2003 to 2011-2012 is taken for the study.

\subsection{Data Collection}

\section{Methodology}

The study is based on secondary data. Information required for the study has been collected from the annual report of AXIS,ICICI,KVB,SIB \& different books, journals ,magazines \& data collected from various bank websites.

\subsection{Statistical Tools}

In this study various statistical tools are used (i.e.,) Mean, Standard deviation, Coefficient of variation \& ANOVA test have been used for data analysis.

\subsection{Hypotheses}

ANOVA is a statistical procedure for determining whether three or more sample means were drawn from populations with equal means. In everyday ANOVA tests the null hypothesis that the population means (estimated by the sample means) are all equal. If null hypothesis is rejected, then we conclude that the population means are not all equal. A more precise formulation of the null and alternative hypotheses for comparing $k$ means is:

$\mathrm{H} 0: \mu 1=\mu 2=\mu \mathrm{k}$

$\mathrm{H} 1$ : at least one pair of means is different, $\mu 1 \ldots \mu 2$

The $\mathrm{F}$ test statistic indicates that there is a significant difference in the mean performances of responses given for concerned samples. Here this computed value is compared with critical values of each group. If $F$ exceeds the critical value for $\mathrm{F}$ at some significance level (usually0.05) it means that there is evidence to reject the null hypothesis in favour of the alternative hypothesis.

\section{Limitation Of The Study}

a) The study is related to a period of 10 years.

b) As the data are only secondary, i.e., they are collected from the published annual reports.

c) Due to limited span of time only profitability ratio is taken for the study.

\section{Overview Of Profitability}

Profitability is the primary goal of all business ventures. Without profitability the business will not survive in the long run. So measuring current and past profitability and projecting future profitability is very important. Profitability is measured with income and expenses. The ability to earn a profit. Infact, efficiency of business is measured in terms of profits. Profitability ratios are calculated to measure the efficiency of a business. The following profitability ratios are.

8.1 Interest Spread \%: Interest spread is the difference between the average lending rate and the average borrowing rate for a bank or other financial institution.

Interest Spread \% =Total interest income minus total interest expenses / Average working fund 
Table: 8.1(a) Analysis of mean, standard deviation \& coefficient of variation.

\begin{tabular}{|c|c|c|c|c|}
\hline \multicolumn{5}{|c|}{ INTEREST SPREAD \% } \\
\hline YEAR & AXIS & ICICI & KVB & SIB \\
\hline $2002-2003$ & 6.28 & 2.77 & 4.88 & 5.33 \\
\hline $2003-2004$ & 5.66 & 3.76 & 4.16 & 4.32 \\
\hline $2004-2005$ & 4.09 & 3.56 & 4.28 & 4.02 \\
\hline $2005-2006$ & 3.14 & 2.67 & 4.13 & 5.18 \\
\hline $2006-2007$ & 3.27 & 3.43 & 4.24 & 5.37 \\
\hline $2007-2008$ & 3.77 & 3.51 & 4.05 & 4.91 \\
\hline $2008-2009$ & 4.24 & 3.66 & 5.34 & 6.73 \\
\hline $2009-2010$ & 3.95 & 5.66 & 4.81 & 6.35 \\
\hline $2010-2011$ & 3.73 & 4.01 & 4.30 & 6.01 \\
\hline $2011-2012$ & 3.91 & 4.44 & 4.37 & 5.32 \\
\hline MEAN & 4.204 & 3.747 & 4.456 & 5.354 \\
\hline SD & 0.949 & 0.807 & 0.394 & 0.799 \\
\hline CV & 22.573 & 21.537 & 8.842 & 14.92 \\
\hline
\end{tabular}

As per table 8.1(a) it has been found that bank wise mean, standard deviation \& coefficient of variation of interest spread of selected banks.SIB \& KVB has highest mean value \& ICICI has lowest value when compare to other banks. Standard deviation of total interest income \& expenses to average working fund of AXIS has 0.949 with highest coefficient of variation of $22.573 \%$ and KVB has 0.394 low standard deviation \& coefficient of variation is $8.842 \%$.

\section{Hypothesis:}

H0: $\mu 1=\mu 2=\mu 3=\mu 4$ (There is no significant relationship between interest spread among different private sector banks in india)

$\mathrm{H} 1: \mu 1 \neq \mu 2 \neq \mu 3 \neq \mu 4$ (There is a significant relationship between interest spread among different private sector banks in india)

Table: 8.1(b) Analysis of ANOVA

\begin{tabular}{|c|c|c|c|c|c|}
\hline Sources of variation & $\begin{array}{c}\text { Sum of } \\
\text { Square }\end{array}$ & $\begin{array}{c}\text { Degrees of } \\
\text { freedom }\end{array}$ & Mean Square & $\begin{array}{c}\text { F (calculated } \\
\text { value) }\end{array}$ & $\begin{array}{c}\text { Table value } \\
\text { (at 5 \% level of significance) }\end{array}$ \\
\hline Between Groups & 13.7159 & 3 & 4.5719 & 7.0087 & 2.8662 \\
\hline With Groups & 23.4837 & 36 & 0.6523 & & \\
\hline Total & 37.1996 & 39 & & & \\
\hline
\end{tabular}

Since the calculated value of $\mathrm{F}(7.0087)$ is greater than the table value (2.8662) as shown in table 8.1(b) ANOVA, null hypothesis is rejected .It is therefore, concluded that there is a significant relationship between the interest spread of (AXIS,ICICI,KVB,SIB) private sectors banks in india.

8.2 Net Profit Margin: Net profit margin is the percentage of revenue remaining after all operating expenses, interest, taxes and preferred stock dividends (but not common stock dividends) have been deducted from a company's total revenue.

Net profit margin $\%=$ Net Profit / Revenue

Table: 8.2(a) Analysis of mean, standard deviation \& coefficient of variation.

\begin{tabular}{|c|c|c|c|c|}
\hline \multicolumn{5}{|c|}{ NET PROFIT \% } \\
\hline YEAR & AXIS & ICICI & KVB & SIB \\
\hline $2002-2003$ & 10.27 & 9.86 & 19.23 & 8.64 \\
\hline $2003-2004$ & 13.14 & 13.67 & 22.12 & 9.21 \\
\hline $2004-2005$ & 14.33 & 16.32 & 16.28 & 1.25 \\
\hline $2005-2006$ & 13.47 & 14.12 & 17.67 & 6.15 \\
\hline $2006-2007$ & 12.01 & 10.81 & 16.47 & 9.71 \\
\hline $2007-2008$ & 12.22 & 10.51 & 16.12 & 10.66 \\
\hline $2008-2009$ & 13.31 & 9.74 & 14.35 & 10.66 \\
\hline $2009-2010$ & 16.10 & 12.17 & 16.82 & 10.69 \\
\hline $2010-2011$ & 17.20 & 15.91 & 16.87 & 11.10 \\
\hline $2011-2012$ & 15.51 & 16.14 & 14.01 & 10.52 \\
\hline MEAN & 13.756 & 12.925 & 16.994 & 8.859 \\
\hline SD & 1.974 & 2.513 & 2.218 & 2.893 \\
\hline CV & 14.350 & 19.422 & 13.051 & 32.656 \\
\hline
\end{tabular}

As per table 8.2(a) it has been found that bank wise mean standard deviation \& coefficient of variation of net profit margin of selected banks. KVB \& AXIS has highest mean value \& SIB has lowest value when compare to other banks. Standard deviation of net profit to revenue of SIB has 2.893 with highest coefficient of variation of $32.656 \%$ and AXIS has 1.974 low standard deviation \& high coefficient of variation is $14.350 \%$ and compare to KVB is low coefficient of variation of $13.051 \%$. 


\section{Hypothesis:}

H0: $\mu 1=\mu 2=\mu 3=\mu 4$ (There is no significant relationship between Net profit margin among different private sector banks in india)

$\mathrm{H} 1: \mu 1 \neq \mu 2 \neq \mu 3 \neq \mu 4$ (There is a significant relationship between Net profit margin among different private sector banks in india)

Table: 8.2(b) Analysis of ANOVA

\begin{tabular}{|c|c|c|c|c|c|}
\hline Sources of variation & Sum of Square & $\begin{array}{c}\text { Degrees of } \\
\text { freedom }\end{array}$ & Mean Square & $\begin{array}{c}\text { F (calculated } \\
\text { value) }\end{array}$ & $\begin{array}{c}\text { Table value } \\
\text { (at 5\% level of significance) }\end{array}$ \\
\hline Between Groups & 336.0579 & 3 & 112.0193 & 17.1513 & 2.8662 \\
\hline With Groups & 235.1242 & 36 & 6.5312 & & \\
\hline Total & 571.1821 & 39 & & & \\
\hline
\end{tabular}

Since the calculated value of $\mathrm{F}(17.1513)$ is greater than the table value (2.8662) as shown in table 8.2(b)ANOVA, null hypothesis is rejected .It is therefore ,concluded that there is a significant relationship between the net profit margin of (AXIS,ICICI,KVB,SIB) private sectors banks in india.

8.3 Return on long term fund: This ratio establishes the relationship between net profit and the long term fund. The term long term fund refers to total investment made in the business of long run.

Return on Long term fund $\%=$ EBIT $/$ Long term fund

TABLE: 8.3(a) Analysis of mean, standard deviation \& coefficient of variation

\begin{tabular}{|c|c|c|c|c|}
\hline \multicolumn{5}{|c|}{ RETURN ON LONG TERM FUND \% } \\
\hline YEAR & AXIS & ICICI & KVB & SIB \\
\hline $2002-2003$ & 157.32 & 119.87 & 93,09 & 186.55 \\
\hline $2003-2004$ & 129.51 & 106.69 & 77.01 & 155.32 \\
\hline $2004-2005$ & 70.55 & 70.54 & 60.43 & 102.59 \\
\hline $2005-2006$ & 88.56 & 56.24 & 63.05 & 82.83 \\
\hline $2006-2007$ & 119.74 & 82.46 & 70.10 & 102.54 \\
\hline $2007-2008$ & 71.17 & 62.34 & 90.21 & 97.58 \\
\hline $2008-2009$ & 97.35 & 56.72 & 101.19 & 112.64 \\
\hline $2009-2010$ & 66.34 & 44.72 & 99.90 & 118.87 \\
\hline $2010-2011$ & 72.29 & 42.97 & 95.12 & 123.92 \\
\hline $2011-2012$ & 88.75 & 52.09 & 110.47 & 155.98 \\
\hline MEAN & 96.158 & 69.464 & 86.057 & 123.882 \\
\hline SD & 28.744 & 24.699 & 16.395 & 30.632 \\
\hline CV & 29.892 & 35.556 & 19.051 & 24.726 \\
\hline
\end{tabular}

As per table 8.3(a) it has been found that bank wise mean, standard deviation \& coefficient of variation of return on long term fund of selected banks.SIB \& AXIS has highest mean value \& ICICI has lowest value when compare to other banks. Standard deviation of EBIT to Long term fund of SIB has 30.632 with coefficient of variation of $24.726 \%$ and $\mathrm{KVB}$ has 16.395 low standard deviation with lowest coefficient of variation of $19.051 \%$

\section{Hypothesis:}

H0: $\mu 1=\mu 2=\mu 3=\mu 4$ (There is no significant relationship between Return on Long term fund among different private sector banks in india)

$\mathrm{H} 1: \mu 1 \neq \mu 2 \neq \mu 3 \neq \mu 4$ (There is a significant relationship between Return on Long term fund among different private sector banks in india)

Table: 8.3(b) Analysis of ANOVA

\begin{tabular}{|c|c|c|c|c|c|}
\hline Sources of variation & $\begin{array}{c}\text { Sum of } \\
\text { Square }\end{array}$ & $\begin{array}{c}\text { Degrees of } \\
\text { freedom }\end{array}$ & Mean Square & $\begin{array}{c}\text { F (calculated } \\
\text { value) }\end{array}$ & $\begin{array}{c}\text { Table value } \\
\text { (at 5 \% level of } \\
\text { significance) }\end{array}$ \\
\hline Between Groups & 15626.49 & 3 & 5208.831 & 7.0937 & 2.8662 \\
\hline With Groups & 26434.26 & 36 & 734.2849 & & \\
\hline Total & 42060.75 & 39 & & & \\
\hline
\end{tabular}

Since the calculated value of $\mathrm{F}(7.0937)$ is greater than the table value (2.8662) as shown in table 8.3(b) ANOVA, null hypothesis is rejected .It is therefore, concluded that there is a significant relationship between the return on long term fund of (AXIS,ICICI,KVB,SIB) private sectors banks in india.

8.4 Return on Net Worth: The return on equity ratio which is also known as the return on net worth is used by investors to determine the amount of return they are receiving from their capital investment in a company. Companies can increase their return on equity percentage by buying back their stock, increasing earnings, or using more debt to fund operations. 
Return on Net worth \% = Profit after tax / Equity share holder fund

Table: 8.4 (a) Analysis of mean, standard deviation \& coefficient of variation.

\begin{tabular}{|c|c|c|c|c|}
\hline \multicolumn{5}{|c|}{ RETURN ON NET WORTH \% } \\
\hline YEAR & AXIS & ICICI & KVB & SIB \\
\hline $2002-2003$ & 25.22 & 17.38 & 25.28 & 24.29 \\
\hline $2003-2004$ & 26.39 & 20.93 & 25.35 & 23.56 \\
\hline $2004-2005$ & 18.19 & 18.86 & 14.30 & 2.05 \\
\hline $2005-2006$ & 18.28 & 14.33 & 16.58 & 9.29 \\
\hline $2006-2007$ & 19.37 & 13.17 & 16.54 & 15.26 \\
\hline $2007-2008$ & 12.21 & 8.94 & 17.50 & 13.27 \\
\hline $2008-2009$ & 17.77 & 7.58 & 17.46 & 15.14 \\
\hline $2009-2010$ & 15.67 & 7.79 & 20.74 & 15.93 \\
\hline $2010-2011$ & 17.83 & 9.35 & 19.65 & 17.25 \\
\hline $2011-2012$ & 18.59 & 10.70 & 18.52 & 19.82 \\
\hline MEAN & 18.952 & 12.903 & 19.192 & 15.586 \\
\hline SD & 3.934 & 4.579 & 3.488 & 6.234 \\
\hline CV & 20.757 & 35.487 & 18.174 & 39.999 \\
\hline
\end{tabular}

As per table 8.4(a) it has been found that bank wise mean, standard deviation \& coefficient of variation of return on net worth of selected banks.KVB \& AXIS has highest mean value \& ICICI has lowest value when compare to other banks. Standard deviation of profit after tax to equity shareholder fund of SIB has 6.234 with highest coefficient of variation of $39.999 \%$ and KVB has 3.488 low standard deviation with lowest coefficient of variation of $18.174 \%$

\section{Hypothesis:}

H0: $\mu 1=\mu 2=\mu 3=\mu 4$ (There is no significant relationship between Return on Net worth among different private sector banks in india)

$\mathrm{H} 1: \mu 1 \neq \mu 2 \neq \mu 3 \neq \mu 4$ (There is a significant relationship between Return on Long term fund among different private sector banks in india)

Table: 8.4(b) Analysis of ANOVA

\begin{tabular}{|c|c|c|c|c|c|}
\hline $\begin{array}{c}\text { Sources of } \\
\text { variation }\end{array}$ & $\begin{array}{c}\text { Sum of } \\
\text { Square }\end{array}$ & $\begin{array}{c}\text { Degrees of } \\
\text { freedom }\end{array}$ & Mean Square & $\begin{array}{c}\text { F (calculated } \\
\text { value) }\end{array}$ & $\begin{array}{c}\text { Table value } \\
\text { (at 5\% level of significance) }\end{array}$ \\
\hline Between Groups & 269.328 & 3 & 89.776 & 3.6938 & 2.8662 \\
\hline With Groups & 874.943 & 36 & 24.303 & & \\
\hline Total & 1144.271 & 39 & & & \\
\hline
\end{tabular}

Since the calculated value of $\mathrm{F}(3.6938)$ is greater than the table value (2.8662) as shown in table 8.4(b) ANOVA, null hypothesis is rejected .It is therefore, concluded that there is a significant relationship between the return on net worth of (AXIS,ICICI,KVB,SIB) private sectors banks in india.

8.5 Return on Asset: (ROA) is a financial ratio that shows the percentage of profit that a company earns in relation to its overall resources (total assets).

Return on asset $\%=$ Net profit $/$ Total asset

Table: 8.5 (a) Analysis of mean, standard deviation \& coefficient of variation.

\begin{tabular}{|c|c|c|c|c|}
\hline \multicolumn{5}{|c|}{ RETURN ON ASSET \% } \\
\hline YEAR & AXIS & ICICI & KVB & SIB \\
\hline $2002-2003$ & 0.99 & 1.13 & 2.02 & 0.95 \\
\hline $2003-2004$ & 1.12 & 1.31 & 2.27 & 0.91 \\
\hline $2004-2005$ & 0.86 & 1.20 & 1.34 & 0.09 \\
\hline $2005-2006$ & 0.98 & 1.01 & 1.50 & 0.47 \\
\hline $2006-2007$ & 120.80 & 270.37 & 196.88 & 102.83 \\
\hline $2007-2008$ & 245.13 & 417.64 & 220.61 & 126.34 \\
\hline $2008-2009$ & 284.50 & 444.94 & 250.26 & 113.76 \\
\hline $2009-2010$ & 395.99 & 463.01 & 297.60 & 129.83 \\
\hline $2010-2011$ & 462.77 & 478.31 & 198.23 & 15.00 \\
\hline $2011-2012$ & 551.99 & 524.01 & 252.68 & 17.87 \\
\hline MEAN & 206.513 & 260.293 & 142.339 & 50.805 \\
\hline SD & 201.198 & 220.390 & 117.973 & 55.738 \\
\hline CV & 97.426 & 84.669 & 82.881 & 109.709 \\
\hline
\end{tabular}

As per table 8.5(a) it has been found that bank wise mean standard deviation \& coefficient of variation of return on asset of selected banks. ICICI \& AXIS has highest mean value \& SIB has lowest value when compare to other banks. Standard deviation of net profit to total asset of ICICI has 220.390 with coefficient of variation of $84.669 \%$ and SIB has 55.738 low standard deviation with highest coefficient of variation of $109.709 \%$ 


\section{Hypothesis:}

H0: $\mu 1=\mu 2=\mu 3=\mu 4$ (There is no significant relationship between Return on asset among different private sector banks in india)

$\mathrm{H} 1: \mu 1 \neq \mu 2 \neq \mu 3 \neq \mu 4$ (There is a significant relationship between Return on asset among different private sector banks in india)

Table: $8.5(\mathrm{~b})$ Analysis of ANOVA

\begin{tabular}{|c|c|c|c|c|c|}
\hline Sources of variation & Sum of Square & $\begin{array}{c}\text { Degrees of } \\
\text { freedom }\end{array}$ & Mean Square & $\begin{array}{c}\text { F (calculated } \\
\text { value) }\end{array}$ & $\begin{array}{c}\text { Table value } \\
\text { (at 5 \% level of } \\
\text { significance) }\end{array}$ \\
\hline Between Groups & 243581 & 3 & 81193 & 2.7555 & 2.8662 \\
\hline With Groups & 1060773 & 36 & 29465 & & \\
\hline Total & 1304354 & 39 & & & \\
\hline
\end{tabular}

Since the calculated value of $\mathrm{F}(2.7555)$ is less than the table value (2.8662) as shown in table 8.5(b) ANOVA, null hypothesis is accepted .It is therefore, concluded that there is no significant relationship between the return on asset of (AXIS,ICICI,KVB,SIB) private sectors banks in india.

\section{Findings}

a) Interest spread of all selected banks SIB has high percent of 6.73 at the end of March 2009 and ICICI has low percent of 2.77 at the end of March 2003.

b) Net profit margin of different banks shows that net increasing the period of March $2003 \mathrm{KVB}$ has highest percent of 22.12 and compare to other banks SIB has low percent of 1.25.

c) Return on long term fund reveals that 186.55 percent over all private sectors banks SIB has highest in the period of March 2003 and ICICI at the end of March 2011 sudden decreasing to 42.97 percent.

d) Return on net worth shows that high percent of AXIS has 26.39 at the end of March 2004 and compare to all other remaining banks SIB has low percent of 2.05 at the end of March 2005.

e) Return on asset gives the clear picture of 551.99 percent has highest in the period of March 2012 and SIB has very low percent of 0.09 at the end of March 2005.

\section{Conclusion}

Profitability of private sector banks in India plays major role in banking sector without profit the investors cannot invest in this business. A strong financial system promotes investment by financing productive business opportunities, mobilizing savings, efficiently allocating resources and makes easy the trade of goods and services. To conclude that there is difference among the mean value of interest spread, net profit margin, return on long term fund and return on net worth and there is no difference among the mean value of return on asset of private banks. So profitability ratios are employed by the management in order to assess how efficiently they carry on their business operations and also it is suggested for the entire bank to take effective steps to improve the operating efficiency of the business.

\section{BOOKS:}

\section{Reference}

[1] M.N Arora (2010), "Accounting for Management", Himalaya Publishing House, Mumbai-400004, PP- 9.13 \& 9.39.

[2] Dalston L.Cecil \& Jenitra L. Merwin (2010) "Management Accounting”, Learntech Press, Trichy-620102, PP- 3.23.

[3] N.P.Srinivasan \& M. Sakthivel Murugan (2010), “Accounting for Management", S.Chand \& Company Ltd, New Delhi - 110055, pp- 212-213.

[4] Dr.S.P Gupta (2010), "Statistical methods", S.Chand \& Sons, New Delhi-110002,PP 1011-1013.

[5] Dr.Priti R.Majhi \& Dr Prafull K .Khatua (2011), "Business Research methods", Himalaya Publishing House, Mumbai-400004, PP278.

[6] C.R.Kothari (2010), "Research Methodology (Methods \& Techniques)", New Age International (P) Ltd Publishers, New Delhi110002, PP-258.

[7] Dr.T.Ramasamy (2011), "Management accounting", Gold books Publishing House, Srivilliputtur-626125, PP-80-86.

[8] Dr.Kajal Chaudhary \& Monika Sharma ,Performance of Indian Public Sector \& Private Sectors banks a Comparative Study ,International Journal Of Innovation, Management \& Technology ,Vol 2,No 3, June 2011,PP- 249-256. 